\title{
THE WAJANG AS A PHILOSOPHICAL THEME*
}

$$
\text { P. J. Zoetmulder, S.J. }
$$

There exist large numbers of modern Javanese texts relating to the wajang. There are, in particular, collections of short resumés of wajang lakon, that is, of plots or scenarios of wajang performances. These collections, called pakem, are more or less manuals for dalang and may contain, apart from the stories themselves in bare outline, technical instructions concerning the music which is to accompany the various scenes, the chants sung by the dalang, etc. A good dalang would, however, consider it beneath his dignity to use these pakem, as he is the bearer of a tradition transmitted orally from father to son or from guru to pupil. That is why there are so few "librettos" of these Javanese "operas" written down just as the dalang speaks them in his eight-to-nine-hour-long performance. Those that exist were written down in the nineteenth century for the benefit of those westerners whose interest in the wajang was aroused and who wanted to read and to study at their leisure what they had heard in those fleeting moments when the wajang was performed, or to study the peculiarities of the dalang's language. Indeed, these pakem (as manuals) can hardly be called literature at all. The complete lakon texts are only to be thought of as literature in a rather general way. But during the 1iterary revival at the court of Surakarta in the early nineteenth century the wajang stories also became a source of inspiration for important works of considerable literary merit. Some of them, put into verse, belong to the best specimins of modern Javanese poetry.

My subject here, however, is only indirectly connected with the wajang and belongs to a quite different domain of modern Javanese letters, the domain of religious and in particular mystico-religious literature. Like nearly all Javanese literature, it is written in verse, but the literary form is of minor importance. It is not read because of the poetic value it might have, but for what it teaches. For these works contain an introduction to and an exposition of a higher knowledge, a gnosis, not destined for the common people. They intend to give to one who is striving after perfection the final answers to the all-important questions about the meaning of 1 ife and existence and the end of man. They teach man's place and position in the universal order, the cosmos, and his relationship to the divine. The knowledge about these fundamental matters leads to the perfection the student craves, or better: it is itself the highest perfection. This knowledge, which is perfection, this gnosis, is in

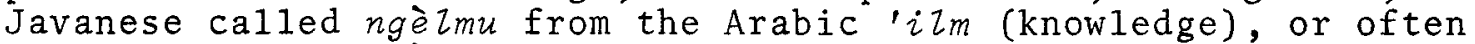
more explicitly ngè lmu kasampurnan (knowledge of perfection). It is a wisdom which should remain hidden from the common people, from the uninitiated. But he who has got an inkling of its existence or has heard vague allusions to it in veiled terms will feel so attracted

* This is a revised version of a lecture delivered at the University of Hawaii, Honolulu, on March 5, 1971. 
that he will go in search of it and will spare no pains to attain it. For him it is, to use a Biblical expression, the precious pearl, in order to buy which one sells all that he has. One sets out in quest of a guru, who is able and willing to introduce one into this esoteric field, becomes his pupil, and lives with him for some time. Finally, at the end of the instruction, the teacher imparts what he considers the essence of his doctrine, often in a short and intentionally obscure formula, communicated at dead of night in an atmosphere of secrecy and mystery. It may happen that the newly initiated, after having gone away and lived with his treasure for some time, feels that it does not give him the satisfaction he had expected from it, or perhaps he suspects that what has been given is after all not the highest obtainable in the field of gnosis--because his guru was unable or unwilling to give him more. Then he will set out again in search of another and better guru and so, wandering about on his quest, he goes from one place to another, until finally he has the feeling of having got what he desired and of having at last attained his goal.

I have in my possession a set of exercise books, thumbed and soiled, in which such a seeker of ngèlmu wrote down his experiences in a journal of his years-long quest, of his expectations and disillusionments, of all the guru he visited and of the differing solutions he received to his questions. As I received it from this student's son and had known the man himself, it was for me a striking proof that what I knew from my books was still an actuality, very much alive not long ago, and perhaps still alive at the present time.

This gnosis is basically a wisdom for the elect, a kind of esoteric or secret knowledge, and the personal contact between the pupil and his guru, the initiandus and his initiator, is considered extremely important. We find this idea expressed also in old literature, Sanskrit as well as $01 \mathrm{~d}$ Javanese, and especially in the Mahābhärata, in the relationship between the Pandawa and their teachers, Bhisma and Drona. When the old Javanese Bharatayuddha describes the scene immediately before the great battle, when Arjuna hesitates at the sight of his adversaries who for the major part are his own relatives, the text says:

On seeing them, Arjuna was visibly overcome with emotion and sadness, as these enemies were all his kindred, without any stranger among them. There were his brothers [cousins] from his father's as we11 as from his mother's side, his uncles... and among them first of all Bhissma and the brahmin [that is, Drona], his own teachers.

It is above all the idea that he has to fight his teachers which is repellent to him. Before the battle starts, the Păndawa come down from their chariots, on foot and unarmed, and proceed to the other side to ask forgiveness, not from their relatives there, but from these same teachers, Bhisma and Drona, for being forced to fight them.

What we find in 01d Javanese fiction lives on still in the reality of the present day. I recall vividly the close relationship which existed between Prince Mangkunegara VII and Ir. J. Moens, both famous in the field of Javanese studies. The former 
was the last great ruler of the Mangkunegaran principality, the latter a western scholar (born in Indonesia) of great brilliance and originality. This was a relationship which was much more than common friendship. Moens explained to me that they had sat at the feet of the same guru, and therefore were "brothers" in a very special sense.

In spite of the esoteric character of this wisdom and the personal character of its communication, it appears that there has never been an absolute prohibition to commit it to writing. Mystico-religious treatises of this kind belong to the oldest products of old Javanese 1iterature. They constitute also a very substantial part of the religious literature written in modern Javanese. One can get an impression how popular this literature still is in certain circles by visiting a bookshop in Jogjakarta or Surakarta. Since Bahasa Indonesia has become the official language of Indonesia, there has been very little printed in Javanese. Yet for these mystico-religious books or booklets there is still a good market, and the shelves are filled with newly printed treatises on Javanese ngel $1 \mathrm{mu}$, either reprints of already existing works or modern adaptations.

It is now that we turn to the subject of this paper: the wajang as a theme in mystico-religious literature. Wajang similes were used in the ancient old Javanese literature, but there they were for the most part merely a literary device, a poetic figure of style. But in one case, in Indra's instruction to Arjuna the Arjunawiwa'ha the purpose of a wajang simile was to illustrate and to make inte1ligible a certain aspect of doctrine. We find also similar wajang comparisons used in later modern Javanese speculative 1iterature. Here comparisons and allegories play an extremely important role. They serve to enliven and to make palatable expositions which by their very nature are theoretical and somewhat arid. They serve also to illustrate the abstract doctrine with concrete examples which appeal to the imagination, bringing some light to obscurities and explaining or even proving argumentation. Exempla non probant (examples prove nothing) may be a sound scholastic axiom, but those who practice it consistently are few, and for most people examples have a great convincing power.

At the same time, however, comparisons and allegories in modern Javanese religious literature achieve something which in a certain sense is the opposite of elucidation, but which in this esoteric literature is valued very highly and more or less belongs to its nature. The supreme wisdom is not something to be communicated in plain and unambiguous terms or to be revealed in its naked truth. It has to be partly veiled and hidden. In this way it remains a mystery. To the seeker of wisdom perhaps it is more attractive and valuable in this form, but it certainly serves a1so to preserve and to protect the doctrine against the unwanted intrusions of the uninitiated or from attacks on the part of more puritan Islamic orthodoxy. From a strictly Islamic point of view, this wisdom may seem very near the boundary which separates or thodoxy from heterodoxy or, indeed, to have crossed it.

There is, finally, a third factor to be taken into consideration. Zeller, in his Phizosophie der Griechen, speaks about the use of comparisons in Neo-Platonism:

This need of using images as a means of expression points to a lack of clearness in thinking; it shows that the speaker has grasped his idea only in and 
through the image, and consequently, only vaguely and indeterminately. It will, in nine out of ten cases, have its cause in the fact that vagueness is the only means to cover up a contradiction.

We must also take into account this possibility in the case of Javanese ngèlmu, in which, as we shall see, the essential unity between God and man is a central topic. That there is always a difficulty in uniting the Absolute with the Limited, the Unconditioned with the Conditioned, will be immediately apparent.

Moving from generalities to the concrete, we will now consider a specific example of how the wajang simile can be used. The example is taken not from any of the theoretical treatises mentioned above but from the Serat Tjentini, a very important work of modern Javanese literature, written probably at the beginning of the nineteenth century. Although composed in the form of a story, it is a veritable encyclopedia of Javanese lore and customs and especially of the Javanese ngèlmu. The principal characters are a11 ardent seekers of esoteric wisdom. On their wanderings through the country in Central and East Java, they miss no opportunity to discuss this wisdom whenever they find a knowledgeable host.

In the passage used as an illustration here, they find themselves together at a village feast, where, among other performances, a wajang play is staged. Most of those who are present belong to a world in which the specific commandments and prohibitions of Islamic law are living realities to be reckoned with. So it happens that, as they observe the wajang puppets moving on the lighted screen, a question arises which for the orthodox Moslems among them is a matter of conscience: what of the injunction, going back to the Prophet and the earliest Islamic law, never to represent human beings in painting, sculpture, or otherwise? Do not wajang puppets fall under this prohibition, and is not the wajang play therefore in open defiance of Islamic orthodoxy? Kidang Wiratjapa, the host, may perhaps feel that the question touches him personally and that it is indirectly a censure of his conduct for making the wajang part of his feast. Yet he shows no embarrassment and, as a clever debater, begins his reply by conceding the objection in part and by acknowledging that it is wel1 founded. He who sees the story represented by the wajang as no more than a tale of human beings, however remote in a legendary past, is indeed guilty of misconduct and transgresses the Law. The results are there for everyone to see. Once a man grows addicted to the wajang and becomes so enslaved to his passion for it that he goes from one performance to another, he ends by forgetting his religion altogether. To him Batara Guru (the supreme god in the wajang story) means more than Allah; Arjuna and Wrekodara mean more than the Prophet and his companions. But in regard to himself (the host) and to people such as his much honored guests, matters are quite different. They are not beguiled by outward appearances but see through them to what is hidden behind these stories of human events. They are able to grasp the lessons conveyed to them with the help of these figures carved in leather. One has to thrust through to what he calls the "perfect insight, the deeper meaning of the wajang, the innermost truth and reality, which remains hidden to the common man, and reveals itself to the initiate only." In the eyes of those who strive after perfection 
this is all a mere symbol pointing to God. The true meaning of the dalang and of the wajang is discovered when one sees them as an external expression of the various ways in which God acts and works in the world.

In order to explain this point, the host then proposes to his guests the following allegory, which, as we shall see, is only an introduction.

The illuminated screen is the visible world. The puppets, which are arranged in an orderly fashion at both edges of the screen at the beginning of the play, are the different varieties and categories created by God. The gedebog, the banana trunk into which the dalang sticks his puppets whenever they have no role to fulfill in the play, is the surface of the earth. The bléntjong, the lamp over the head of the dalang behind the screen, which brings to life the shadows on the other side, is the lamp of life. The gamelan, the orchestra which accompanies the play with its motives and melodies fixed in accordance with the various persons and events projected on the screen, represents the harmony and mutual relationship of everything that occurs in the world.

The creatures, which appear in the world in uncounted numbers and in an astounding variety of forms, may become an obstacle to true insight, impeding understanding of the deeper meaning of all that is created. He who refuses to be led by one who is wiser than he [that is: the uninitiated who is unwilling to put himself under the guidance of a guru] will never see that God is in and behind everything. He is deceived by form and shape. His sight becomes troubled and confused, and he loses himself in a void, while the true significance of the universe remains hidden to him. He goes astray on a path full of obstacles for, lacking the right knowledge, the true meaning of all that appears before his eyes continues to evade him.

God is not described explicitly as the dalang conducting the

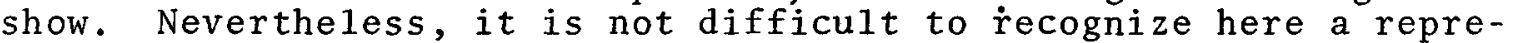
sentation of the relationship between Creator and Creation, which is also found in the religious literature of other countries. God is the invisible puppeteer of the shadow play or marionette theater, who holds in His hands and moves every single human being in all his actions, and who orders and guides a11 events according to His Sovereign Will. In Islamic mysticism we find this idea in the words of the great Ibn-a1-'Arabi:

Whosoever wishes to grasp the full significance of the truth that it is God who works behind the veil of created things, let him observe the shadow theater and the shadows on the screen. . . C Confronted with the world in its manifold shape, most people behave like those little children in the audience whose minds are wholly absorbed by what appears on the stage. Only those who are versed in divine things, the "knowers of God," reflect 
and recognize that Allah has made it into a symbol for His servants so that they may understand that the world is related to God in the same way as the puppets are related to him who moves them.

In an example from India, Jñannadeva, a mystic of the twelfth century, writes in his Jñ̄aneşwar $\vec{\imath}$ :

Man vainly says that he is the agent of actions. He forgets that he is only an occasional cause. . . . Creatures are like inanimate puppets in a show. The dolls fall down in a confused fashion as soon as the string that holds them together is taken away.

It is the creatures' total dependence on their Creator, and also the danger of becoming so preoccupied with the created as to forget the Creator, which is expressed by these images. But let us go back to our host and his esoteric speculations. After having used the allegory of the wajang to explain that the world can be an obstacle to finding God, he abandons for a moment the wajang comparison to choose different imagery: Creation is like a piece of writing, left by God to be read by those that love Him, a communication from Him by which they may learn to know Him, or at least may be incited to inquire into the full truth that is expressed by these symbols in an imperfect way.

The beauty of that writing inspires one with a longing of love; it arouses the desire to go beyond these revelations of His Divine Will and to penetrate into the cognition of His Divine Being, with which this Will is identical. For $\mathrm{He}$ is the Most High, in whose Power it is to create and to direct the universe. His Sovereignty is without alteration. He is the One only and no other is associated with Him. His Holiness is supreme and eternal.

And then, suddenly, the comparison with the wajang is taken up again and presented in a form which is so full of paradox that it must have had a confusing and bewildering effect on the audience.

Inflamed by love, the eminent dalang takes the decision to make himself known. He wants to be seen; he prepares himself to reveal his secret being by the use of symbols in such a way that what becomes visible seems to be a plurality, although He is One and there is nothing beside Him. He is like a dalang in a state of rapture and beside himself. There are no wajang puppets to be seen and, nevertheless, he speaks as if in a trance. It is not his intention to present a lakon [the special plot chosen for the performance] and, nevertheless, the whole story is finished with, complete with all its necessary parts: the hero has accomplished his apprenticeship in the house of a guru and received his initiation, and the story has been concluded in the traditional way with a wedding. He who hires the dalang to perform the play is not yet there, and 10 , the man has already received his pay. The play is finished, and the dalang has not 
yet started. The story proceeds and develops, although the kekayon ${ }^{i}$ has not yet been pulled out of the banana trunk.

The accumulation of paradoxes continues.

The screen is still and deserted, and nevertheless full of life and motion. The gamelan orchestra drones, but not a single instrument is visible, no ketuk, ketjèr, or gendèr, no violin or flute, no saran or gambang, no drum or gong. The play is about to start, the puppets stand ready--and the story has already ended. But where is he, then, the puppeteer? The spectators feel confused and bewildered, unable to understand it, as if overcome by sleep. Who is it that invited the dalang to give a performance, while the puppets were not even made ready?

But now the host puts an end to his guests' bewilderment. Here are his own words:

This all is an expression in symbolic language of the Highest Wisdom. Its meaning is as follows: God Most Holy is the exalted dalang. He, the Creator of the Universe, Who has made it all, has unalterably predestined and fixed our lot before we were born. Fortune or misfortune, a short or a long lifespan, success or failure, it has been apportioned to us when we were still leading a hidden existence in the place of concealment. At the moment man is conceived in the womb, his life story has already been enacted and completed. Nothing is missing; nothing is superfluous. It is the wisdom of the A11-Knowing which has arranged everything to the last detail. The Most High is the exalted dalang. The outward shape and the division into categories and species of all visible things, in short the coming into appearance of everything that exists, these are the puppets on the screen. It is the dalang who disposes and guides them in all their actions and movements.

This explanation resolves the apparent contradictions and brings light into the obscurity. God is the Most High, One without a second, alone in His Divine Solitude, before the Creation comes forth from His hands. But it is not an aloneness which is emptiness, not a solitude which is devoid of life, but which is instead fullness and richness. For His Infinite Being contains everything, and His Supreme Intellect and Sovereign Will have predisposed and arranged al1 things before they come into existence.

These beliefs could all be fitted very well into the doctrine of Allah and his takdir (predestination) as it is taught in orthodox Islam. It is, however, not this doctrine which is alluded to by the wajang allegory as developed by Kidang Wiratjapa, the host in the Tjentini story, but rather the allusion is to a conception of the

1. The kekayon is the trigonal figure in the middle of the screen, which is set aside when the play begins. 
universe and of the relation between the Absolute and the Contingent, between God and man, which is frequently found in Sumatran and Javanese mysticism. It is common property of Islamic mysticism in general and has roots in Neo-P1atonism.

All that exists forms one great unity, which is seen as unfolding and developing along seven stages or grades of being, the seven martabat. These seven stages range from the undifferentiated, unqualified and undivided one to the concrete fullness of the visible world, with the Perfect Man as the final stage. He is the end of the emanation, of the descent of being from the one to the Multiple. He is the starting point for the reascent. A1l stages bear Arabic terms. The first three are called Ahadiyah, Wahda, and wăhidïyah, terms which all contain the word "One" and connote a certain form of "oneness." Abadiyah is the stage of completê non-differentiation. Individuation begins in Wahda but only as a state of general cognoscibility and of potentiai dis tinction. Not until the third stage, Wăhidiyah, do distinct notions arise. These three stages constitute the sphere of the intelligible and the abstract, as distinguished from the phenomenal and the concrete. It is the sphere of the divine and partakes of its Oneness. In the first stage we find the Absolute in its transcendence, inexpressible in words, inconceivable by concepts. The second stage is that in which the Absolute contemplates itself and sees its own being as containing the potentiality for a differentiation into multiplicity. This contemplation develops in the third stage to a cognition, in which all things are conceived according to their proper individuality, with their proper qualities and activities, but still joined together in this one divine cognition and so constituting a oneness-in-multiplicity. The transition from the one to the Multiple, from potential to actual plurality, is called in orthodox terminology (although philosophically inexactly) the transition from the sphere of the Creator to that of the Created. In the triple division of the following stages (the world of the spirits, the world of forms, and their combination in the world of the bodies), we perceive an echo of Aristotelian hylomorphism, adapted to the needs of the Neo-Platonic system. This is not, however, relevant to our subject here.

What the wajang passage quoted above is intended to express in its paradoxical way is the divine sphere of the three first martabat. In this sphere the whole world of created beings is already present but in an invisible way. Al1 beings have already enacted their life stories before they have been begun. The gamelan is sounding its melodies in perfect harmony and in the right arrangement before there is a single instrument to be seen.

In the explanation given by the host to enlighten his audience the expressions which he uses to speak about God as the exalted dalang point in the same direction. They are what I might cail "technical" terms, which are in common use in the expositions of the wujudiyah, the doctrine of the oneness of al1 that exists, in which the cosmic scheme of the seven stages has been inserted. It forms the doctrinal background of most of Sumatran mysticism and of Javanese mysticism as well, insofar as the latter is closely connected with Islamic ideas and thought. These allusions were enough for those among his audience who were no strangers to this field. For them another passage in the allegory, omitted above, also would not have had the obscurity which 
it may have for us. After having said, "Who is it that invited the dalang to give a performance, while the puppets were not even made ready?" the host continues: "The story [the lakon] is that of the Prince of Janggala on his wanderings over the earth, while the kraton of Janggala accompanies him and does not remain behind in a far distance." The Prince of Janggala is indubitably Panji, who leaves his kraton to wander about, concealing his identity and giving wajang performances under the name Dalang Jaruman. The meaning of this passage cannot have caused difficulties for a really knowledgeable audience. In other places in this mystico-religious literature, Panji is used as à symbol for God, present in everything in the world, as it is his emanation, and thus, as it were, wandering about in disguise, unnoticed by those who are ignorant of his real identity. That he seems to have left his kraton, the divine sphere, is only an illusion. The visible world is an unfolding, a manifestation of his divine being. It is essentially one with him. He has not left his kraton but has taken it with him. That the world has its own existence is an illusion. Apart from him there is no reality at all.

Thus, here there are echoes of Neo-Platonism, of the medieval Arabic monism of Ibn-al-'Arabi and his school, of the Sumatran mysticism of unity, and all included in a wajang performance in a village of the Javanese countryside. This mixture is typical for a culture which through the centuries underwent influences of various kinds, absorbing them without losing its own specific character.

We might think this allegory very profound and its teaching esoteric in the highest degree. But Kidang Wiratjapa appears to be of a different opinion. When he continues his exposition of the ngè $1 \mathrm{mu}$, occasioned by the wajang play before him, it turns out that the foregoing is only the outer aspect of what has to be considered as the "true meaning of the religion of the Prophet." There is an inner aspect, too. "Outer and inner" are expressed in Javanese with terms borrowed from the Arabic: Zaip-batin. These are the stereotyped expressions in this literature for "exoteric-esoteric." So now we are prepared for a sequel to these wajang speculations, intended to impart a still higher wisdom, a second part which is valued more highly than the first.

Now the dalang is no longer presented in opposition to his puppets. He is no longer the man who handles them from the outside, but rather he enters them and moves them from within. The image is, therefore, no longer based on the reality of what is seen in the wajang. But can there be any objections to that? Is such an uncommon and rather perplexing image not exactly what is wanted and most appropriate to convey that higher insight into the relationship between God and man, which only a few are allowed to approach?

Now everything takes place inside man. That which gives life and moves him and causes him to exist is like the dalang who has entered his puppets. There he lives and acts in an invisible way. Only he who has not yet attained that higher wisdom thinks that the puppets move themselves and shape their own life stories. We have here the idea of the indwelling of God in man, the concept of the one divine life present in every person, a theme that again and again recurs in the ngè lmu.

The first part of our wajang allegory was based on the wujūîyah, the doctrine of the oneness of all existence, a doctrine which had developed within Islam and which betrayed its origin in its Arabic 
terminology. Now, in the second part, we are dealing with a different mysticism, which I might call suksma-mysticism. In its doctrinal content and terminology it points to India. The individual soul is part of the universal soul, which dwells in the innermost depth of man. To find the Absolute, one need only look into oneself. In India the divine element in man is generally called atman (in its transcendental form, paramatman, the supreme soul). In Javanese it is designated by various terms: rasa, in which the meanings of Sanskrit rasa (essence, taste) and Sanskrit rahasya (secret, mystery) have blended; urip (life); and especial1y suksma (.the immaterial, the soul), to which is prefixed sanghyang when used to denote its supreme state. The suksma in man is united and indeed identical with sanghyang suksma, the Divine Absolute.

So we find in the esoteric part of Wiratjapa's exposition passages such as:

Dalang and puppets, the gamelan, the banana-trunk, the screen, and the lamp, they are all united in one being. The dalang is life itself. The body, acting and speaking, is the puppet appearing on the screen of the world and moved by that life. . . The entering of the suksma into the body is the entering of the dalang into the puppet... So we are all dominated by the suksma in us, which is life itself. Our life story is the lakon of the wajang. We are the spectacle ourselves.

But who is the spectator? The host answers this question somewhat obscurely: "The witness of all that lives." The meaning of these words becomes clear in another ngèlmu text which contains the popular story of Wrekodara, or Bhima, the second of the Pandawa brothers, who in the Javanese tradition has also become a seeker of wisdom, sent out in quest of the elixir of life. After a dangerous journey which takes him to the bottom of the sea, he meets Déwarutji and is initiated into the "knowledge of perfection." His guru, too, uses the comparison of the wajang to explain this teaching. He says explicitly that Sanghyang Suksma is the owner of the house who decides to give a wajang performance and who therefore invites the dalang, but he stays in his house and remains unseen. This dalang is the individual soul, the one who moves the puppet $\dot{s}$ but from the inside. Here the relationship between the Divine in its Absoluteness, unqualified and immutable, inaccessible to the senses and to the intellect and, on the other hand, its partial manifestation as the individual soul in man has found an appropriate expression.

In the foregoing we have seen the two principal trends of thought in Javanese mysticism. On the one hand, a11 that exists was seen as an emanation or diffusion of the One, the Absolute, united with it and not separated, in a unity of being. On the other hand, God was said to dwell in the innermost part of man as his deepest reality, his soul, his true ego. These two trends come together in and are superseded by a much more radical doctrine, a complete monism, in which every distinction between God and man vanishes. It was the aim of both trends to achieve union with the Divine. They were an attempt to bridge the abyss which, according to orthodox Islamic doctrine, separates the Absolute from the 
Contingent, the Creator from his Creation, the Master from the Servant (in Javanese, gusti and kawula). In ngèlmu the final goal of all endeavors to attain perfection is summed up in the words manunggiling kawula-gusti, "the becoming-one of Master and Servant." In the terms of the wajang allegory, it is an endeavor to understand the true nature of the relationship between dalang and wajang, between the puppeteer and his puppets. Now, however, the question is unavoidable: Has not every relationship an element of reciprocity? The puppets depend upon the dalang in all their doings. But is not the reverse equally true? Does not the dalang depend upon his puppets? That is indeed what observation of the wajang teaches us. The puppets move in the way the dalang moves them; they say what the dalang causes them to say. But is the dalang totally independent of his puppets? Can he do with them what he likes, make them move and speak as his fancy takes him? Can he cause the demon king to act as if he were a princess, or Arjuna as if he were his clownish companion Pétruk? The idea is too absurd to be taken seriously. It is therefore evident that there is a mutual interdependency. Without dalang no wajang, but also without wajang no dalang. And the same appilies to what is signified in the esoteric comparison, the relationship between God and man. As long as one speaks about the union between master and servant, the very words master and servant include the concept of mutual dependency. Without master no servant, but also without servant no master. Can manunggiling kawula-gusti, the becoming-one of master and servant, be the highest perfection, if there is still an element of dependency in it? Can it fulfill the aspiration of him who strives after Absolute Oneness, radically and without compromise, if it is a union of two beings? For him the final word must be: There is no master and there is no servant.

The confession of faith in orthodox Islam is: Là izaha izzá 'Zzāh ("There is no God but Allah"). But he who seeks Absolute Unity retains only the first part: There is no God. That is the highest wisdom. That is the unconditioned surrender to the quest of the One, which is true Islam. And he is perfectly aware that in this way he has placed himself outside the fold of Moslem orthodoxy. We find statements like: One is not a true Moslem so long as one has not become a kafir, an infide1. Or, again,

What is the final word about dalang and puppets? What is the highest truth concerning master and servant?... Dalang and wajang, master and servant, even your own being, these are something relative only, which do not deserve consideration. This is the final solution which ngèlmu offers. Everything has vanished from sight, overpowered by the One. The perfect faithful, prophets and saints, have become blind and have lost hearing, speech, and taste. Soul and body are absorbed into nothingness, as in the time when they did not yet exist. This is True Perfection: to have done away with all praise and worship and with the acknowledgment of any as Lord. A11 duality has been eliminated in a state of Pure Nothingness. The servant has gone, without becoming master. This is the highest vision.

With this climax our survey of the various forms of Javanese gnosis has come to an end. We proceeded from the doctrine of the 


\section{6}

essential Oneness of all being, via that of the indwelling of the Divine in man, to an extreme and radical monism. We saw how the basic tenets of each of them were illustrated and explained with the help of a comparison with the wajang theater, and how in particular the relationship between dalang and puppets was used to illustrate the relationship between the Absolute and the Contingent, between God and man. Here we reached also a sort of climax, albeit a rather negative one. When monism was carried through to its logical conclusion, the distinction between dalang and puppets was seen as the last vestige of a duality which had been definitely done away with. They did not merge into each other; they just vanished. And with this rather suicidal end our discussion, too, must close. 